\title{
Can Triamcinolone acetonide, platelet-rich plasma, and pentosan polysulfate sodium induce oxidative stress in cultured equine chondrocytes?
}

\author{
Heloisa Einloft Palma ${ }^{*}$ Miguel Gallio $^{2}$ (D) Gabriele Biavaschi da Silva ${ }^{3}$ Camila Cantarelli $^{3}$ \\ Patrícia Wolkmer ${ }^{1}$ Rodrigo Fernando dos Santos Salazar ${ }^{1}$ (D) Julien Wergutz ${ }^{4}$ \\ Luciana Maria Fontanari Krause ${ }^{4}$ Alexandre Krause ${ }^{5}$ Karin Erica Brass ${ }^{3}$ \\ Flavio Desessards De La Corte ${ }^{3}$
}

\footnotetext{
${ }^{1}$ Centro de Ciências da Saúde e Agrárias, Universidade de Cruz Alta (UNICRUZ), Rodovia Jacob Della Méa, 98020-290, Cruz Alta, RS, Brasil. E-mail: heinloft@hotmail.com. "Corresponding author.

${ }^{2}$ Curso de Medicina Veterinária, Instituto de Desenvolvimento Educacional do Alto Uruguai (IDEAU), Getúlio Vargas, RS, Brasil.

${ }^{3}$ Departamento de Clínica de Grandes Animais, Universidade Federal de Santa Maria (UFSM), Santa Maria, RS, Brasil.

${ }^{4}$ Departamento de Saúde, Universidade Franciscana (UFN), Santa Maria, RS, Brasil.

${ }_{5}^{5}$ Departamento de Clínica de Pequenos Animais, Universidade Federal de Santa Maria (UFSM), Santa Maria, RS, Brasil.
}

ABSTRACT: Progressive deterioration and loss of articular cartilage are the final degenerative events common to osteoarthritis (OA). Reactive oxygen species (ROS) play an important role in this chondrocyte catabolic activity, leading to cell death and matrix components breakdown. Intra-articular corticosteroid injections such as triamcinolone acetonide have been used to control pain and inflammation associated with OA. New treatments for $\mathrm{OA}$, platelet-rich plasma and pentosan polysulphate sodium have also been used and further investigations are necessary to determine their safety in joint cells. In this in vitro study, the use of these three substances (triamcinolone acetonide, platelet-rich plasma, and pentosan polysulphate sodium) in healthy chondrocytes did not alter the antioxidant status when compared to control groups, indicating that they could be considered safe in healthy conditions.

Key words: antioxidant enzymes, catalase, glutathione peroxidase, lipid peroxidation.

Acetonido de triancinolona, plasma rico em plaquetas e pentosano polissulfato sódico podem ocasionar estresse oxidativo em cultivo de condrócitos de equinos?

RESUMO: A deterioração progressiva e perda da cartilagem articular são os eventos finais da osteoartrite (OA). Espécies reativas de oxigênio (ROS) têm papel importante na atividade catabólica de condrócitos, levando a morte celular e quebra dos componentes da matriz. Injeções intra-articulares de corticosteroides, como com o acetonido de triancinolona, são usadas para controle da dor e inflamação associadas à OA. Novos tratamentos para a OA, como o plasma rico em plaquetas e o pentosano polissulfato sódico, também tem sido utilizados e necessitam de maiores investigações para determinar sua segurança para as células articulares de equinos. Neste estudo in vitro, o uso destas três substâncias (acetonido de triancinolona, pentosan polissulfato de sódio de plasma rico em plaquetas) em condrócitos saudáveis de equinos não alterou o status antioxidante quando comparado aos grupos controle, indicando que puderam ser considerados seguros em condições saudáveis.

Palavras-chave: enzimas antioxidantes, catalase, glutationa peroxidase, peroxidação lipídica.

\section{INTRODUCTION}

Hyaline cartilage provides a low-friction gliding surface, with increased compressive strength and it is known to be wear-resistant under normal circumstances. It consists of chondrocytes and a dense extracellular matrix composed primarily of water, collagen, and proteoglycan. Articular cartilage is a highly-specialized tissue with poor regenerative capacities, because of its low metabolic activity. In this way, the balance between anabolism and catabolism of the matrix is crucial for this tissue homeostasis (BHOSALE \& RICHARDSON, 2008; PEARLE et al., 2005).

Chondrocyte metabolism is responsible for the maintenance of a stable and abundant extracellular matrix. Unfortunately, at some point the biosynthetic anabolic activity is unable to keep the pace with the degradative catabolic activity, and degeneration of the tissue results, leading to the occurrence of diseases such as osteoarthritis (OA) (SANDELL \& AIGNER, 2001).

The wear and tear is the most commonly quoted theory for the pathogenesis of OA in horses, supported by its presence in younger horses used for athletic activity (KIDD et al., 2001). GALLIO et al. (2014) reported a high incidence of articular lesions in horses under three years old, its occurrence in young ages aggravates the consequences of the disease, once $\mathrm{OA}$ has a detrimental effect in the equine industry because of the delayed return to athletic performance. 
In response to mechanical stress, immunomodulatory and inflammatory mediators, as some cytokines involved with the articular damage in OA, chondrocytes produce abnormal levels of reactive oxygen species (ROS) and reactive nitrogen species (HENROTIN et al., 2003). ROS play a crucial role in regulation of a number of chondrocyte activities such as cell activation, proliferation and matrix remodeling (HENROTIN et al., 2005). The ROS are capable of degrading many components of the joint in the presence of insufficient antioxidant defenses, and as a result, ROS have been implicated in the pathogenesis of joint disease in horses (DIMOCK et al., 2000).

Substances that protect articular cartilage during the course of OA have been termed chondroprotective agents (VERBRUGGEN, 2006). Among the medications available for the treatment of OA, corticosteroids are the most potent regarding its anti-inflammatory activity and have been a mainstay in the treatment of joint disease for nearly half a century (CARON, 2005). Triamcinolone acetonide (TA) is one of the most commonly used corticosteroid, especially because of its safety and beneficial effects (CARON, 2005; WILLIAMS \& BRANDT, 1985).

Although, TA is considered safe, there is a progressive need to find other therapeutic options to retard the progression of osteoarthritis, once some studies demonstrated that TA can be harmful to joints. FUBINI et al. (2001) showed that corticosteroids could decrease chondrocyte expression of matrix proteins contributing to cartilage degeneration. SUNTIPARPLUACHA et al. (2016) assessed the cytotoxicity and oxidative stress caused by TA on chondrocytes from OA knees. The TA induced chondrotoxicity by increasing oxidative stress and altering expressions of genes involved in cell death. Exact mechanisms of chondrotoxicity are not completely understood, but could be a result of the oxidative stress caused by TA.

Platelet-rich plasma (PRP) has been extensively studied in the dentistry and nowadays is one of the most popular biological products for equine regenerative medicine. The PRP contains a mix of growth factors, cytokines derived from platelets and clotting proteins that results in anabolic effects on both cells and tissue cultures, been important in the processes of tissue repair (SMITH et al., 2014; WASTERLAIN et al., 2012). An advantage of using PRP is that patients can return to sports more quickly, as compared with patients treated with traditional surgical protocols (LOPEZ-VIDRIERO et al., 2010).

Another chondroprotective drug to control OA progression is pentosan polysulphate sodium
(PPS). It is known that PPS stimulates proteoglycan synthesis in vitro and suppresses cartilage degradation in animals with OA (GHOSH, 1999). FREAN et al. (2002) also demonstrated an increase in proteoglycan synthesis occurring at chondrocytes cultures from horses treated with PPS. In veterinary medicine, PPS is used mainly for prophylaxis and /or treatment of OA despite of limited scientific evidence proving its efficacy in horses (KRAMER et al., 2014).

Those substances are considered safe to the articular environment, once they do not interfere with the articular anatomical structure. However, the aim of this study was to investigate the oxidative profile resulting from their use on chondrocytes cultures, which can result in cell death. Also, the evaluation of oxidative parameters may be an early detection of tissue injury.

\section{MATERIALS AND METHODS}

\section{Isolation of articular chondrocytes of horses}

For this study, metacarpophalangeal joints of five adult horses with age varying between 5 to 12 years old were collected from an abattoir. Animals were considered healthy through clinical and radiographic evaluation. The limbs were sectioned at the carpometacarpal joint, cleaned and the hair removed.

Under aseptic conditions in a laminar flow chamber, the selected joints were surgically exposed and the cartilage was removed in small fragments. Chondrocytes were isolated from articular cartilage as described by CRUZ et al. (1990) with some modifications. Briefly fragments were placed in a Petri dish containing DMEM (Dulbecco Modified Eagle's Medium) culture medium supplemented with $10 \%$ fetal bovine serum (FBS), $60 \mathrm{U} / \mathrm{mL}$ penicillin, $60 \mu \mathrm{g} / \mathrm{mL}$ streptomycin and $2 \mathrm{mmol} / \mathrm{L}$ glutamine. Then cartilage fragments were washed three times and underwent enzymatic digestion in Falcon tubes in order to isolate the chondrocytes. For this, chondrocytes were incubated in Pronase medium for $1 \mathrm{~h} 30 \mathrm{~min}$ and, after washing three times, were incubated in Falcon tubes for approximately 18 hours in collagenase medium. Two incubations that compose the digestion process were carried out at $37{ }^{\circ} \mathrm{C}$ in a humidified atmosphere with $95 \%$ air and $5 \% \mathrm{CO}_{2}$.

After digestion with collagenase, cells were washed three times in culture medium to eliminate the enzyme and thus halting digestion. Cell suspension was collected into a $50 \mathrm{~mL}$ Falcon tube and the volume supplemented by addition of culture medium DMEM. Afterwards, it was allowed a five minutes 
rest to the cell suspension, so that small fragments of non-digested cartilage could be separated, and isolated from the chondrocytes suspension. Cell suspension was aspirated and transferred to a new Falcon tube. The cell suspension in the Falcon tube was then centrifuged at $200 \mathrm{x} g$ for five minutes. After the third wash, the cells were suspended in culture medium supplemented with 5\% (v/v) FBS.

Cell density of the suspension obtained was determined by counting cells in Neubauer's hemocytometer. Cell viability was evaluated simultaneously using the Trypan Blue exclusion test. As a rule, more than $98 \%$ of viable cells were obtained in each isolation. The experiment was repeated with five different joint culture cells.

\section{Chondrocyte culture and treatments}

Chondrocytes were cultured in Petri dishes (60 $\mathrm{mm}$ in diameter) or in six-well culture wells under confluence conditions at a density of $0.5 \times 10^{6}$ cells $/ \mathrm{cm}^{2}$. Chondrocytes were cultured for a mean period of 21 days in DMEM culture medium supplemented with $10 \% \mathrm{FBS}, 60 \mathrm{U} / \mathrm{mL}$ penicillin, $60 \mu \mathrm{g} / \mathrm{mL}$ streptomycin and $2 \mathrm{mmol} / \mathrm{L}$ glutamine in humidified atmosphere, at $37{ }^{\circ} \mathrm{C}$ and $5 \% \mathrm{CO} 2$. After an average period of 21 days, when the cells had reached a confluence of approximately $90 \%$, they were transferred to the cell culture dishes.

After reaching confluence around $90 \%$, after a period of three days average, the treatment of the cells started. For this purpose, cell cultures were distributed in four groups (G): G1: control chondrocytes without any treatment; G2: chondrocytes + PRP (500.000 platelets/well); G3: chondrocytes + triamcinolone $(0.06 \mathrm{mg} / \mathrm{mL}) ; \mathrm{G} 4$ : chondrocytes + pentosan sodium polysulfate $(4 \mathrm{mg} /$ $\mathrm{mL})$. Volume and doses used in each treatment were adjusted according to what is recommended for the treatment of animals presenting joint lesions in the routine clinic cases (CARON, 2005).

\section{Preparation of PRP}

Platelet Rich Plasma (PRP) was produced from blood collected from the jugular vein of healthy horses, with a collection bag containing CPDA-1 as anticoagulant. After the centrifugation protocol, which consisted of two steps, the first centrifugation was with a force of $400 \mathrm{x}$ g for ten minutes, for the separation of the plasma, which was immediately transferred to two new Falcon tubes and centrifuged again with $800 \mathrm{x} \mathrm{g}$ strength for 10 minutes to form the platelet pellet. The supernatant was discarded, leaving $10 \mathrm{~mL}$ of PRP. PEREIRA et al. (2013) previously established this protocol in our laboratory. The pellet was resuspended and homogenized with a fraction of the supernatant plasma. A PRP sample and a whole blood sample were sent for laboratory analysis, for platelet counting and confirmation of PRP concentration prior to use of the product in the cell culture.

\section{Oxidative profile}

Oxidative damage was evaluated in cultured chondrocytes after cells were detached from the bottom of the wells with the aid of trypsin. Then, the trypsin was rinsed off and the DMEM medium added to the wells of the culture dish. Chondrocytes and DMEM medium after being removed from the culture dish were placed in Eppendorf tubes and stored at $-80^{\circ} \mathrm{C}$ for later processing.

Lipid peroxidation in cell culture was determined according to OHKAWA et al. (1979), after incubation of the sample at $95^{\circ} \mathrm{C}$ in water bath, with subsequent cooling the sample to stop the reaction. Reading was performed by spectrophotometry at $495 \mathrm{~nm}$. The amount of thiobarbituric acid reactive substances (TBA-RS) was expressed in nmol of malondialdehyde (MDA)/g tissue.

Activity of catalase (CAT) in cell culture was determined by the method of NELSON \& KIESOW (1972), by the addition of hydrogen peroxide to the samples and peroxide degradation analysis by spectrophotometry. Activity was expressed as U/mg protein.

Glutathione peroxidase (GPx) catalyzes the reaction of hydroperoxides with reduced glutathione; its activity was measured in a spectrophotometer at $340 \mathrm{~nm}$, as already described in the literature (FLOHE, GUNZLER, 1984).

\section{Trypan blue}

The viability test was carried out by the Trypan Blue method, with the same volumes of the culture suspension and Trypan blue dye placed in an Eppendorf tube. The sample was then homogenized and placed in a Neubauer chamber for cell counting and differentiation of living and dead cells. Cell mortality was verified by color change, with the penetration of blue dye into the cell cytoplasm (LOUIS \& SIEGEL, 2011).

\section{MTT assay}

MTT assay can measure the level of reductase in mitochondria which reflects the level of cell metabolic activity. In this assay, the activity of NAD (P) H-dependent cellular oxidoreductase 
represents the total number of viable cells. This enzyme reduces the MTT 3-(4,5-dimethylthiazol-2yl)-2,5-diphenyltetrazolium bromide into formazan (insoluble). After the treatments, cells were collected from the culture plates and $100 \mu \mathrm{l}$ of suspended cells were added to each well of a 96-well plate, and added $10 \mu \mathrm{l}$ of sterilized MTT solution $(5 \mathrm{mg} / \mathrm{ml})$. After a 3 h-incubation period, $100 \mu \mathrm{l}$ of solubilization solution containing $10 \% \mathrm{SDS}$ and $0.1 \% \mathrm{HCl}$ was added to each well. 12 hours later, the optical density was measured at $595 \mathrm{~nm}$ using a plate reader.

\section{Statistical analysis}

Two-way ANOVA was used for the statistical analysis of the values obtained, followed by Duncan's multiple comparisons test. Results were considered significant when $\mathrm{p}<0.05$ and expressed as mean \pm standard deviation.

\section{RESULTS AND DISCUSSION}

In this study, the use of pentosan, triamcinolone and PRP in healthy chondrocytes did not alter the antioxidant status when compared to control groups. No statistical differences were observed between the groups studied when lipid peroxidation was evaluated and neither was the activity of catalase and glutathione peroxidase indicating that they could be considered safe in healthy articular conditions (Figure 1A-C).

When the imbalance between oxidants and antioxidants is large enough to induce cellular and/ or tissue structural and/or functional changes, the situation is called "oxidative stress" and is considered as an abnormal catabolic event (HENROTIN et al., 2005). It is important to note that drugs used in the treatment of osteoarthritis should not be associated with cell damage or a stimulus that causes oxidative damage or changes in the activity of the antioxidant enzymes present in the joint.

The underlying mechanism of cartilage matrix degradation in OA is poorly understood but the ROS are implicated as the main causative factors. These ROS are capable of oxidizing and, subsequently, damaging numerous components of the joint, including collagen, proteoglycans and hyaluronan (OSTALOWSKA et al., 2006).

Fortunately, several lines of anti-oxidant defense exist both intra- and extracellular to protect the knee joint against damage from ROS and other oxidants. Scavengers and detoxifying reactions, catalyzed meanly by anti-oxidant enzymes catalase (CAT), and glutathione transformation enzymes, including glutathione peroxidase (GPx) provide defense against ROS. In synovial fluid, these antioxidant enzymes often coexist (OSTALOWSKA et al., 2007; ALPASLAN et al., 2000).

Lipid peroxidation and disruption of lysosomal integrity are also implicated in the pathogenesis of inflammatory processes. Lipid radicals increase edema and produce prostaglandins and various endoperoxides by increasing vascular permeability, inflammation, and chemotaxis. An increased lipid peroxidation in rheumatoid arthritis and increased levels of thiobarbituric acid-reactive material in the synovial fluid were reported in previous studies (ALPASLAN et al., 2000). OSTALOWSKA et al. (2006) observed that all patients with OA significantly increased antioxidant enzymes activities (CAT, GPx) and MDA concentration in synovial fluid, and decreased synovial fluid viscosity when compared to the control subjects.

GRIGOLO et al. (2003) reported that chondrocytes, from OA knees, activated in vitro produced ROS and significantly accelerated lipid peroxidation compared to those activated in vivo. In other study, OSTALOWSKA et al. (2006) did not observe a high concentration of MDA, which indicates lipid peroxidation, in the synovial fluid from patients with OA. In our study, we did not observe a significant difference in oxidative profile in culture of chondrocytes. We did not expect to find any changes since the cells had been removed from healthy animals. The high cell viability reported in the cultures (approximately 98\%) corroborates the low activity of the antioxidant enzymes analyzed as well as the lipid peroxidation.

Frequent use of corticosteroids for joint diseases is of concern regarding the potential toxicity to articular cartilage. The TA, a commonly used intraarticular corticosteroid, is clinically non deleterious. Many studies describe that glucocorticoids can reduce cartilage integrity and chondrocyte cells viability. WILLIAMS \& BRANDT (1985) demonstrated that when TA was injected into knee of guinea pigs with OA, there was a reduction in femoral condylar cartilage fibrillation, osteophytes were much less prominent and cell loss was less extensive when compared to non-treated joints. PELLETIER et al. (1995) showed a protective effect of corticosteroid injections on OA cartilage lesions under prophylactic and therapeutic conditions. Effect of TA may be mediated through a direct reduction in the expression and synthesis of proteolytic enzymes.

In our study, chondrocytes from animals with osteoarthritis were not used so that there was no 


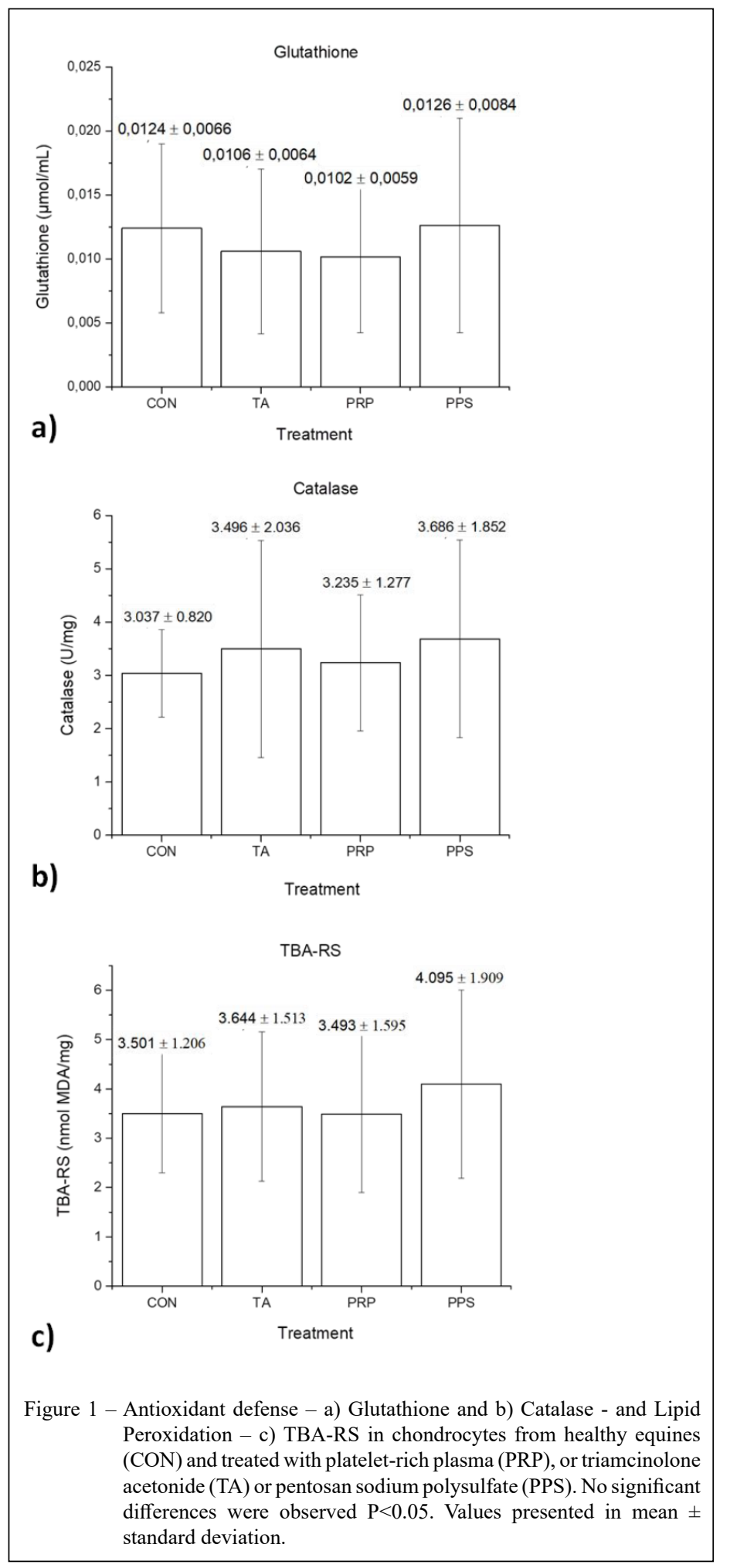

Ciência Rural, v.49, n.7, 2019. 
interference from altered cell biology in the analysis of oxidative stress, since the objective of the study was to test the substances. Thus, possibly this was the reason we did not observe significant differences in relation to the oxidative profile of the cells treated with TA. However, an important finding was that the drug itself was not able to cause damage to the cultured cells.

A novel therapeutic option to animals with OA is treatment with PRP using intra-articular injections. Studies evidenced that PRP can be considered safe to joints, and because of its antiinflammatory effects. Those are partially attributable to reduced nuclear factor $(\mathrm{NF} \kappa \mathrm{B})$ signaling. Precise nature of the connection between PRP signaling and downstream NFKB pathway molecules is not fully established, but the underlying mechanisms are becoming increasingly understood (ANDIA \& MAFFULLI, 2013).

In 2014, TOHIDNEZHAD et al. studied the effects of PRP in primary human osteoblast cells. They demonstrated that PRP not only leads to increase the endogenous vascular endothelial growth factor, but also it may be involved in preventing oxidative damage through the nuclear erythroid 2-related factor-antioxidant response element signaling. There is a lack of controlled clinical studies proving a clinical beneficial effect of PRP, but with this study, we added more data supporting the use of concentrated platelets. As no change in antioxidant enzyme activity and lipid damage profile were observed in PRP-treated chondrocytes, their use was considered safe for chondrocytes.

Regarding to PPS use to treat OA, there is a lack of studies evaluating the effects of this drug in OA chondrocytes. In our study, it was not evident any detrimental effect with PPS administration in cell cultures. There was no evidence of a higher antioxidant defense when compared to control nontreated group.

\section{CONCLUSION}

In this study, those three treatment options were not harmful to the chondrocytes in vitro, allowing high cellular viabilities and low antioxidant activity.

\section{ACKNOWLEDGEMENTS}

The authors thank Frigorífico Foresta, from São Gabriel, RS, Brasil and the pharmacist Zanoni Segala, for the financing of supplements to carry out the research. This study was funded by the Fundação de Apoio à Tecnologia e Ciência (FATEC) -
Universidade Federal de Santa Maria (UFSM), (5.03.0025 - grant), and was financed in part by the Coordenação de Aperfeiçoamento de Pessoal de Nível Superior (CAPES), Brazil - Finance code 001.

\section{AUTHOR'S CONTRIBUTIONS}

All authors contributed equally for the conception and writing of the manuscript. All authors critically revised the manuscript and approved of the final version.

\section{DECLARATION OF CONFLICT OF INTERESTS}

The authors declare no conflict of interest. The founding sponsors had no role in the design of the study; in the collection, analyses, or interpretation of data; in the writing of the manuscript, and in the decision to publish the results.

\section{REFERENCES}

ALPASLAN, C. et al. Effect of arthrocentesis and sodium hyaluronate injection on nitrite, nitrate, and thiobarbituric acidreactive substance levels in the synovial fluid. Oral Surgery Oral Medicine Oral Pathology, v.89, n.6, p.686-690, 2000. Available from: <https://bit.ly/2JuEp1Q>. Accessed: May, 15, 2019. doi: $10.1067 /$ moe. 2000.105518 .

ANDIA, I; MAFFULLI, N. Platelet-rich plasma for managing pain and inflammation in osteoarthritis. Nat. Rev. Rheumatol., v.9, n.12, p.721-730, 2013. Available from: <https://bit.ly/2VAjzzD>. Accessed: May, 15, 2019. doi: 10.1038/nrrheum.2013.141.

BHOSALE, A.M.; RICHARDSON, J.B. Articular cartilage: structure, injuries and review of management. British Medical Bulletin, v.87, p.77-95, 2008. Available from: $<$ https://bit.ly/2EmmI0c $>$. Accessed: May, 15, 2019. doi: $10.1093 / \mathrm{bmb} / \mathrm{ldn} 025$.

CARON, J.P. Intra-articular injections for joint disease in horses. Vet Clin Equine, v.21, p.559-573, 2005. Available from: $<$ https:// bit.ly/2EmdX6r>. Accessed: May, 15, 2019. doi: 10.1016/j. cveq.2005.07.003.

CRUZ, T.F. et al. Inverse correlation between tyrosine phosphorylation and collagenase production in chondrocytes. Biochem. J., v.269, p.717-721, 1990. Available from: $<$ https://bit. ly/2WU4Sc9>. Accessed: May, 15, 2019. doi: 10.1042/bj2690717.

DIMOCK, A.N. et al. Evidence supporting an increased presence of reactive oxygen species in the diseased equine joint. Equine Veterinary Journal, v.32, n.5, p. 439-443, 2000. Available from: <https://bit.ly/2HsU8MT>. Accessed: May, 15, 2019. doi: 10.2746/042516400777591129.

FLOHÉ, L.; GÜNZLER, W. A. Assays of glutathione peroxidase. Methods in Enzymology, v.105, p. 114-120, 1984. Available from: $<$ https://bit.ly/2JwBaqQ $>$. Accessed: May, 15, 2019. doi: 10.1016/ S0076-6879(84)05015-1.

FREAN, S.P. Effects of anti-arthritic drugs on proteoglycan synthesis by equine cartilage. J Vet Pharmacol Ther., v. 25, n. 4 , p.289-298, 2002. Available from: <https://bit.ly/2HFLVnh>. Accessed: May, 15, 2019. doi: 10.1046/j.1365-2885.2002.00404.x. 
FUBINI, S.L. et al. Corticosteroids alter the differentiated phenotype of articular chondrocytes. Journal of Orthopaedic Research, v.19, p.688-695, 2001. Available from: <https://bit. ly/30wKzUl>. Accessed: may, 15, 2019. doi: 10.1016/S07360266(00)00060-7.

GALLIO, M. et al. Bone changes prevalence in the tarsus of Crioulo yearlings up to 26 months of age. Ciência Rural, v.44, n.8, 2014. Available from: <https://bit.ly/2EkXGia>. Accessed: May, 15, 2019. doi: 10.1590/0103-8478cr20131171.

GHOSH, P. The pathobiology of osteoarthritis and the rationale for the use of pentosan polysulfate for its treatment. Seminars in Arthritis and Rheumatism, v.28, n.4, 1999. Available from: $<$ https://bit.ly/2VFdB0C > Accessed: May, 15, 2019. doi: 10.1016/ S0049-0172(99)80021-3.

GRIGOLO, B. et al. Enhanced lipid peroxidation in synoviocytes from patients with osteoarthritis. The Journal of Rheumatology February, v.30, n.2, p.345-347, 2003. Available from: $<$ https://bit. ly/2waqVzS $>$. Accessed: May, 15, 2019.

HENROTIN, Y. et al. The role of reactive oxygen species in homeostasis and degradation of cartilage. Osteoarthritis and Cartilage, v.11, p.747-755, 2003. Available from: $<$ https://bit. ly/2JOR7bf $>$. Accessed: may, 15, 2019. doi: 10.1016/S10634584(03)00150-X.

HENROTIN, Y. et al. Oxygen and reactive oxygen species in cartilage degradation: friends or foes? Osteoarthritis and Cartilage, v.13, p.643-654, 2005. Available from: <https:// bit.ly/2VBZA3J $>$. Accessed: may, 15, 2019. doi: 10.1016/j. joca.2005.04.002.

KIDD, J.A., et al. Osteoarthritis in the horse. Equine vet. Educ., v.13, n.3, p.160-168, 2001. Available from: $<$ https://bit. ly/2HrhIJQ>. Accessed: May, 15, 2019. doi: 10.1111/j.20423292.2001.tb00082.x.

KRAMER, C.M. et al. Survey of the therapeutic approach and efficacy of pentosano polysulfate for the prevention and treatment of equine osteoarthritis in veterinary practice in Australia. Australian Veterinary Journal, v.92, n.12, 2014. Available from: $<$ https://bit. ly/2ElsaAH>. Accessed: May, 15, 2019. doi: 10.1111/avj.12266.

LOUIS, K.S., SIEGEL, A.C. Cell Viability Analysis Using Trypan Blue: Manual and Automated Methods. In: STODDART, M. Mammalian Cell Viability. Methods in Molecular Biology. New York: Humana Press, 2011. Cap.2, pag.7-12.

LOPEZ-VIDRIERO, E. et al. The use of platelet-rich plasma in arthroscopy and sports medicine: optimizing the healing environment. The Journal of Arthroscopic and Related Surgery, v.26, n.2, p.269-278, 2010. Available from: <https:// bit.ly/2QehoRo>. Accessed: May, 15, 2019. doi: 10.1016/j. arthro.2009.11.015.

NELSON, D.P.; KIESOW, L.A. Enthalpy of decomposition of hydrogen peroxide by catalase at 25 degrees $\mathrm{C}$ (with molar extinction coefficients of $\mathrm{H} 2 \mathrm{O} 2$ solutions in the UV). Analytical Biochemistry, v. 49, p. 474-478, 1972. Available from: <https:// bit.ly/2QiITJI>. Accessed: May, 15, 2019. doi: 10.1016/00032697(72)90451-4.

OHKAWA, H. et al. Assay for lipid peroxides in animal tissues by thiobarbituric acid reaction. Analytical Biochemistry, $v$ 95, p. 351-358, 1979. Available from: <https://bit.ly/2Ek00pp>. Accessed: May, 15, 2019. doi: 10.1016/0003-2697(79)90738-3.
OSTALOWSKA, A. et al. Lipid peroxidation and antioxidant enzymes in synovial fluid of patients with primary and secondary osteoarthritis of the knee joint. Osteoarthritis and Cartilage, v. 14, p.139-145, 2006. Available from: <https://bit.ly/2VEdYZl>. Accessed: May, 15, 2019. doi: 10.1016/j.joca.2005.08.009.

OSTALOWSKA, A. et al. Oxidant and Anti-Oxidant Systems of Synovial Fluid from Patients with Knee Post-Traumatic Arthritis. Journal of Orthopaedic Research, v.25, n.6, p.804-812, 2007. Available from: <https://bit.ly/2LX8vgJ>. Accessed: May, 15, 2019. doi: 10.1002/jor.20357.

PEARLE, A.D. et al. Basic Science of Articular Cartilage and Osteoarthritis. Clinics in Sports Medicine, v.24, p.1-12, 2005. Available from: <https://bit.ly/2ABYn4Q>. Accessed: May, 15, 2019. doi: 10.1016/j.csm.2004.08.007.

PELLETIER, J.P. et al. The in vivo effects of intraarticular corticosteroid injections on cartilage lesions, stromelysin, interleukin-1, and oncogene protein synthesis in experimental osteoarthritis. Laboratory Investigation, v.72, n.5, p.578-586, 1995. Available from: $<$ https://bit.ly/2JRrXbN $>$. Accessed: May, 15, 2019.

PEREIRA, R.C.F. et al. Evaluation of seven platelet-rich plasma processing protocols in the equine species. Ciência Rural, v.43, n.6, p.1122-1127, 2013. Available from: <https://bit. ly/2JuBZAs $>$. Accessed: May, 15, 2019. doi: 10.1590/S010384782013005000052

SANDELL, L.J; AIGNER, T. Articular cartilage and changes in arthritis. An introduction: Cell biology of osteoarthritis. Arthritis Res, v.3, p.107-113, 2001. Available from: < https://bit. ly/2Hrnqvg>. Accessed: May, 15, 2019. doi: 10.1186/ar148.

SMITH, R.K.W. et al. The current 'state of play' of regenerative medicine in horses: what the horse can tell the human. Regen. Med., v.9, n.5, p.673-685, 2014. Available from: <https://bit. ly/2HrmNlo>. Accessed: May, 15, 2019. doi: 10.2217/rme.14.42.

SUNTIPARPLUACHA, M. et al. Triamcinolone acetonide reduces viability, induces oxidative stress, and alters gene expressions of human chondrocytes. Eur Rev Med Pharmacol Sci, v.20, n.23, p.4985-4992, 2016. Available from: <https://bit.ly/2VO9UKM>. Accessed: May, 15, 2019.

TOHIDNEZHAD, M. et al. Role of platelet-released growth factors in detoxification of reactive oxygen species in osteoblasts. Bone, v. 65 , p.9-17, 2014. Available from: <https://bit.ly/2JTzM0W>. Accessed: May, 15, 2019. doi: 10.1016/j.bone.2014.04.029.

VERBRUGGEN, G. Chondroprotective drugs in degenerative joint diseases. Rheumatology, v.45, p.129-138, 2006. Available from: <https://bit.ly/2WiaUq1>. Accessed: May, 15, 2019. doi: 10.1093/rheumatology/kei171.

WASTERLAIN, A.S. et al. Contents and formulations of plateletrich plasma. Operative Techniques in Orthopaedics, v.22, p.3342, 2012. Available from: <https://bit.ly/2YC7tbd $>$. Accessed: May, 15, 2019. doi: 10.1053/j.oto.2011.11.001.

WILLIAMS, J.M.; BRANDT, K.D. Triamcinolone hexacetonide protects against fibrillation and osteophyte formation following chemically induced articular cartilage damage. Arthritis and Rheumatism, v.28, n.11, 1985. Available from: <https:// bit.ly/2VF9YHU>. Accessed: May, 15, 2019. doi: 10.1002/ art. 1780281111 . 